\title{
Authentic Assessment to Enhance Students'social Responsibilty Character
}

\author{
Ida Rohayani*, Endang Danial A R, Elly Malihah, Dadang Sundawa \\ Universitas Pendidikan Indonesia \\ Bandung, Indonesia \\ rohayani94@student.upi.edu
}

\begin{abstract}
Student' responsible characters are individual and social moral implementation conducted by a student in his involvement in the community to provide behavioral propriety standards. A high school student who is considered to have a selfidentity as adolescents are expected to have empathetic to solve the environment social irregularities occur. When their involvement in social order becomes part of a lesson, then the judgment must be authentic. This study presents authentic assessment descriptions of students' processes, products, and evaluations who have undertaken social studies that have an impact on improving social order. Authentic assessment is executed by giving a duration of 3 months for preparing and doing research. Assessing students' products through presentation in the class is watched and judged by other students as an audience. Provide interpretation of good or bad value as research judgment. This study show that students who are authentic judged have more empathy improve their individual and social character than students who are judged conventionally based on test.
\end{abstract}

Keywords-authentic assessment; evaluation research basedlearning model; learning processess; learning's product; social responsibility

\section{INTRODUCTION}

Citizenship learning process by implementing civic competence in shaping the good citizen urgently needed. Various methods of proper evaluation are important factors in shaping citizenship identity. It becomes part of the policy in the classroom, school, and even government. Therefore, in Europe, there is a study on how to measure the competence of citizens who expressed the importance of the establishment of a model, method, up to the proper assessment of learning in civic and citizenship education. There remains considerable appetite among policy-makers in Europe, at a national and supranational level, to strengthen the evidence base for civic and citizenship education through the collection of up-to-date data. That data can then be used to help further shape policies and practices and measure outcomes in this area [1]. Especially in this study the facts and data are used as a basis for classroom policy by the teacher.

While a good learning should sharpen students' social skills, critical attitudes, provide solutions, become responsible citizens, and provide a special experience to continue studying to the next level. Row input high school students are seen as a teaching subject that is able to maximize its potential as a result of learning, so the teacher should not assume the students do not have provision in learning. The latest learning solutions reveal collaborative learning between theoretical, personal experience, observation, and guidance aimed at optimizing the internalization process. Lecture model, exposure, and question and answer, will be more meaningful when students are actively present in front of the class. Teachers guide and direct the material materials individually so that service to students more leverage. The vast scope of Civics science can be used as a means to solve social problems in society, and can even be an anchor of the social science (the core of social studies) so that the learning model can be done in various ways, supportive media support, and raises the problem everyday so that students are made easier to understand the Civic theory in accordance with the world and their ability called authentic learning.

But the authentic learning process must synergize with the assessment that has been done, so that learning can be measured success. Hart analyzes how a judgment can become authentic, i.e. when students are engaged in a worthy, significant, and meaningful task [2]. Among them is assessing the appearance of learning activities, not the traditional test. They engage in high-level thinking skills and coordinate wider knowledge boundaries. The teacher communicates to the student the intent of the work that has been done by the student by making an explicit standard where the work will be assessed. So in this case the authentic judgment is to set the standard instead of assigning assessment tools. How does an authentic assessment of a learning process impact on good social character? This study tries to reveal how an authentic assessment in the research learning process in improving the good social character of students.

\section{RESUlt AND DisCUSSION}

This study attempts to reveal the correlation between authentic assessment of the social responsibility of high school students by linking things that should be in the assessment of the Civic learning process including:

- Awareness as a citizen (civic literacy)

- Civic engagement social communication,

- The ability to participate as a citizen (civic skill and participation) 
- Citizenship reasoning (civic knowledge)

- Responsible citizenship participation (civic participation and civic responsibility

In the authentic assessment students learn the content of the material then apply it to be a meaningful and relevant task. What needs to be understood deeply about learning is the meaningfulness of life. Life is not rigid, only a choice of four, or multiple choices. Authentic judgment is strongly able to influence metacognition and process information that is the key to learning [3] also develop high-level thinking (HOTS: Higher Order Thinking Skills). Life consists of many choices, problems, situations, and scope that requires critical thinking, problem solving, and synthesis analysis. These skills can be developed through various interactions with collaborative activities with other students. For students who want to succeed after graduation, they must prepare themselves and be guided by these profitable skills. Higher education programs should focus on the same acquisition and apply knowledge and skills [4]. Students should be active participants either made or are being responsible for their own learning.

To answer the problem formulation, that is how the relationship between Authentic Civic Learning with Citizen Character. Next will be used canonical analysis test tool to see the big influence of one independent variable with some dependent variable. With the independent variable in this study, it is Authentic Civic Learning, while the dependent variable is Citizen Character consisting of Moral Knowing (Y1), Moral Action (Y2), and Moral Feeling (Y3). Software used to perform this Canonical Correlation test is SPSS 16 by using syntax for test.

Wilk's Lambda test is used to see the significance of the independent variables with dependent variables, in this study is whether the Authentic Variables Learning Civics have influence on Moral Knowing, Moral Action, and Moral Feeling together. In other words, it can be said that there is a meaningful influence between the independent variable with the dependent variable. With the help of SPSS 16, we obtained the Wilk's Lambda test table as follows.

TABLE I. WILK'S LAMBDA TEST

\begin{tabular}{|l|c|c|c|c|c|}
\hline \multicolumn{6}{|c|}{ Multivariate Tests of Significance $(\mathbf{S}=\mathbf{1}, \mathbf{M}=\mathbf{1} / \mathbf{2}, \mathbf{N}=\mathbf{1 7})$} \\
\hline $\begin{array}{c}\text { Test } \\
\text { Name }\end{array}$ & Value & Exact $\boldsymbol{F}$ & $\begin{array}{c}\text { Hypoth } \\
\text { DF }\end{array}$ & $\begin{array}{c}\text { Error } \\
\text { DF }\end{array}$ & $\begin{array}{c}\text { Sig. of } \\
\boldsymbol{F}\end{array}$ \\
\hline Pillais & .51488 & 12.73615 & 3.00 & 36.00 & .000 \\
\hline Hotellings & 1.06135 & 12.73615 & 3.00 & 36.00 & .000 \\
\hline Wilks & $\mathbf{. 4 8 5 1 2}$ & $\mathbf{1 2 . 7 3 6 1 5}$ & $\mathbf{3 . 0 0}$ & $\mathbf{3 6 . 0 0}$ & $\mathbf{. 0 0 0}$ \\
\hline Roys & .51488 & & & \multicolumn{5}{|c|}{ a. Note. F statistics are exact. }
\end{tabular}

Test Hypothesis:

$\mathrm{H}_{0}$ : Canonical model does not mean $(\mathrm{r}=0)$

$\mathrm{H}_{1}$ : Canonical model means $(\mathrm{r} \neq 0)$

Test Statistic: Reject $\mathrm{H}_{0}$ if the probability value $(\mathrm{Pr}<\mathrm{F})$ is smaller than the significance level of this study that is $10 \%$ or 0.1 .
Decision: From the results that have been obtained in table 2, obtained the value of $\operatorname{Pr}$ is 0.000 while the level of significance in this study is $10 \%$. Thus based on the test statistic, Ho is rejected because the probability value is smaller than the level of significance $(\operatorname{Pr}<\mathrm{F})$.

Conclusion: It can be concluded that the proposed canonical correlation model between the independent variables $\mathrm{X}$ (Authentic civics Learning) with the bound variable Y1 (Moral Knowing), Y2 (Moral Action), and Y3 (Moral Feeling is meaningless, or it can be said that there is a significant influence between the independent variable with the dependent variable at the level of significance research $10 \%$.

After testing the canonical correlation model is meaningful, then we will look for canonical correlation value. Using SPSS 16 , the value of the canonical correlation is 0.623 .

TABLE II. CANONICAL CoRrelation VAlue IN Model 1 (F1)

\begin{tabular}{|l|l|c|c|c|}
\hline \multicolumn{5}{|c|}{ Eigenvalues and Canonical Correlations } \\
\hline Root & No. Eigenvalue & Pct. & Cum. Pct. & Canon Cor. \\
& & & & \\
\hline 1 & 1.06135 & 100.00000 & 100.00000 & $\mathbf{. 7 1 7 5 5}$ \\
\hline
\end{tabular}

Canonical Correlation value in this study is 0,7175 , obtained on the basis of Guilford scale can be said that the strength of the relationship between variables Authentic Learning Civics with the dependent variable Moral Knowing (Y1), Moral Action (Y2), and Moral Feeling (Y3) together are moderate. From the value of canonical correlation obtained, can also be generated Coefficient Determination (R2) which describes the Big Contribution of independent variables against the three dependent variables. Thus, the contribution of Authentic Civics Learning to the dependent variable is 0,7175 $\mathrm{x} 0,7175=0,5148$ or it can be said that the Authentic variable of Civic Learning can explain 51,48\% of the Moral Knowing, Moral Action and Moral Feeling variables; while the remaining $48,52 \%$ is explained by factors other than Authentic Civic Learning.

\section{A. Value of Canian Correlation between $X$ with $Y$}

In the last part of this canonical analysis test, will be searched for the influence of independent variables with each dependent variable, namely Authentic Learning Civics with Moral Knowing, Authentic Learning Civics with Moral Action, Authentic Learning Civics with Moral Feeling. By using the loading factor which is the output resulting from this canonical correlation analysis can be known the value of each correlation. By using SPSS 16, the value of Loading Factor in the Correlation between input variables and canonical variables is as follows.

TABLE III. CANONICAL LOADING FACTOR

\begin{tabular}{|l|l|}
\hline \multicolumn{2}{|c|}{ Correlations between DEPENDENT and canonical variables } \\
\hline \multicolumn{2}{|c|}{ Canonical Variable } \\
\hline Variable & $\mathbf{1}$ \\
\hline MK & .37315 \\
\hline MF & .42666 \\
\hline
\end{tabular}


In table 3, obtained the calculation results of Loading Factor which can be interpreted as the correlation value of each dependent variable in model 1 with the free variable, as follows.

- Correlation $\mathrm{X}$ with $\mathrm{Y} 1=0,373$, the closeness of the relationship is moderate, and positive.

- Correlation X with Y2 $=0.426$, the closeness of the relationship is moderate, and is positive.

- Correlation $\mathrm{X}$ with Y3 $=0.896$, the closeness of the relationship is very strong, and is positive.

The data shows that the influence of authentic assessment with a social character in the form of moral knowing, moral action, and moral feeling there is a correlation value of positive and significant influence. This shows that the authentic assessment process is very influential on changes in responsible social behavior. The same statement is expressed in a study of Authentic as High impact assessment practices demonstrate the advantages of authentic assessment. The author lists the advantages of authentic assessment:

- Students are motivated to do their best in these tasks.

- Faculty is likely to support changes in curriculum predicated on authentic assessment results.

- Authentic assessment creates a universal understanding of learning that incentivizes both educators and learner to join reform processes [5].

Visually illustrated the relationship values contained in figure 1 as follows.

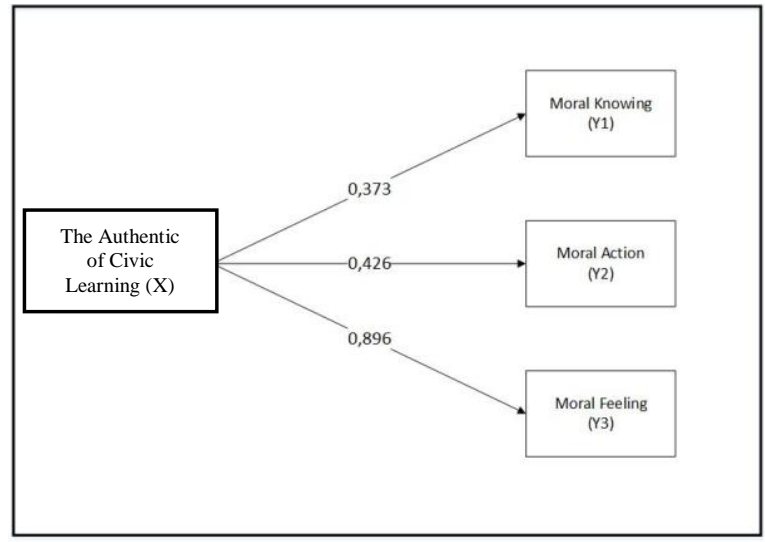

Fig. 1. The value of loading factor variable is independent towards the dependent variable.

\section{B. Conclusions of Canonal Analysis}

The canonical relationship model formulated, i.e. Authentic Civic Learning variable as independent variable with the dependent variables of Moral Knowing, Moral Action, and Moral Feeling produce a meaningful relationship model. Thus, the authentic variable of Civic Learning can explain the three dependent variables. The influence of Authentic Variables of Civic Learning with Citizen Character variable is $\mathbf{0 , 7 1 7 5}$ based on Guilford scale, the value has meaning that the strength of the relationship is moderate. Variable Authentic of Civics Learning can explain 51,48\% variable Citizen Character, while the rest of $\mathbf{4 8 , 5 2 \%}$ dependent variables explained by variables other than Authentic Civics Learning. Individual influence variable Authentic Learning Civics with Citizen Character is as follows.

- Authentic Civic Learning with Moral Knowing is 0,373 (weak, positive).

- Authentic Learning Civics with Moral Action is equal to 0,426 (medium, positive)

- Authentic Learning Civics with Moral Feeling is 0,896 (very strong, positive)

\section{CONCLUSION}

Based on the results of this study, there is a correlation between authentic assessment in the learning of Civics on the good character proposed by Lickona that is moral knowing, moral action, and moral feeling as the foundation of a citizen performing responsible acts as society [6]. The strengthening of the results of the process can be done in various ways, such as teachers can observe the daily life of students at school by reminding them of the results of his research. Sensitivity to social problems students honed. Make the school a civic laboratory. Facilitate the teacher in the assessment because we can assess the cognitive, affective and psychomotor students with the provision of research tasks. When students perceive assessment practices as innovative and relevant, they perceive that complete and comprehensive learning has been given significantly alteration [7]. Students who see the assessment closely related to various learning activities, they will be very enthusiastic in learning. This is what will make the understanding and appreciation of the scope of the subject better, then this also develops intrinsic motivation to the learning process.

\section{REFERENCES}

[1] D. Kerr and J. Lopez, Studying Civic and Citizenship Education in the European Context. New York, 24-28 March. NFER Publisher, 2008.

[2] D. Hart, Authentic Assessment A Handbook for Educator, Menlo Park, California: Addison-Wesley Publishing Company, 1994.

[3] S. Azim and M. Khan, "Authentic Assessment: An Instructional Tool to Enhance Students' Learning," Academic Research International, vol. 2, pp. 314-320, 2012.

[4] T.T. Vu and G. Dall'Alba, December. "Exploring an Authentic Approach to Assessment for Enhancing Student Learning." Paper presented at the annual meeting of the Australian Association for Research in Education Brisbane, Australia, 2008.

[5] J. Zilvinskis, "Using Authentic Assessment to Reinforce Student Learning in High-Impact Practices," Assessment Update, vol. 27, no. 6, 2015

[6] T. Lickona, "Educating For Character How Our Schools Can Teach Respect and Responsibility", New York-Toronto-London-SydneyAuckland: Bantam Books, 1992

[7] S.P. Kearney and T. Perkins, "Improving Engagement: The Use of 'Authentic Self and Peer Assessment for Learning' to Enhance the Student Learning Expe- rience." Paper presented at the Academic and Business Research Institute Conference, Las Vegas, Nevada, 2011. 